\title{
Strategic Choice And Institutional Ambiguity: A History Of Entrepreneurial Emergence In Rural China
}

Scott Droege, Ph.D., Western Kentucky University, USA

Michelle Lane, Ph.D., Western Kentucky University, USA

Shane Spiller, Ph.D., Western Kentucky University, USA

\begin{abstract}
This conceptual research suggests that path dependence historically created a limited array of entrepreneurial choices in rural China including various forms of collective and private business ownership. However, collective ownership historically gave rural Chinese entrepreneurs increased sociopolitical legitimacy thereby increasing access to resources such as capital; however, during China's reform era many rural entrepreneurs chose private rather than collective ownership, an economically illogical choice. This seemingly illogical choice resulted in changes in China's institutional fabric such that the most historically illogical choice-private business ownership - became the most logical choice. This suggests that entrepreneurial choice extends beyond economic rationality to a more complex environment of options.
\end{abstract}

Keywords: entrepreneurial choice, Chinese economic development, Chinese economic reform, institutional ambiguity

\section{INTRODUCTION}

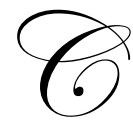

hina is a nation of paradox. It is against this paradoxical, sometimes contradictory, backdrop in which this study is set. The specific paradox addressed here concerns entrepreneurial choice. A seemingly logical choice for Chinese entrepreneurs as China moved from a command economy toward a market economy would have been to develop a business that has adequate access to capital and other resources, assistance from powerful institutions, and some protection against property expropriation. All of these characteristics were benefits of collective forms of organization as China emerged from third-world status to a major global economic power. The paradox is that for many of China's entrepreneurs, this seemingly logical choice was not the path taken. Instead, some entrepreneurs willingly set aside these benefits in pursuit of private ownership, even when the very term "ownership" was ambiguous at best.

Focusing on rural China, this study examines the entrepreneurial choice between two competing business forms - collective organization and private enterprise - that were available to Chinese entrepreneurs once China began its journey toward capitalism. From a broader perspective, the overarching contribution of this research is to provide an explanation of why entrepreneurs would select a seemingly more risky method of business formation when a less risky choice is available.

This conceptual research begins with a historical overview of key sociopolitical events in China's since 1949 to illustrate the path dependence of contemporary entrepreneurial choice. Second, we highlight entrepreneurial choice in an ambiguous environment. Third, entrepreneurial choice in terms of collective versus private enterprise is examined. Fourth, we draw conclusions based on the combination of these topics. Our basic argument is that (1) path dependence historically created a limited array of entrepreneurial choices in rural China, (2) this limited array of entrepreneurial choices included both collective and private business ownership, (3) collective ownership historically gave rural Chinese entrepreneurs increased sociopolitical legitimacy thereby increasing access to 
resources such as capital, but (4) many rural entrepreneurs during China's reform era chose private rather than collective ownership, an economically illogical choice, resulting in (5) changes in the institutional fabric such that the most historically illogical choice - private business ownership — became the most logical choice suggesting that (6) entrepreneurial choice extends beyond economic rationality to a more complex environment of options. This argument using historical patterns in China's transition from a command to a market economy illustrate contemporary thinking regarding strategic choice; that is, such choices are an amalgam of the resource-based view of the firm, specific industry conditions, and macro-level institutional factors (Peng, 2003; Peng, Wang \& Jiang, 2008). Taken together, these create co-evolutionary patterns that have changed the structure of private business owners and the state (Krug \& Hendrischke, 2008).

\section{THE HISTORICAL CONTEXT OF ENTREPRENEURIAL CHOICE IN RURAL CHINA}

Mintzberg and Westley (1992) emphasize the importance of context to capture the full richness of phenomena. The context of entrepreneurial choice is no exception. It is difficult to interpret China's present without some understanding of its past; choices and actions are affected by the path-dependent context in which they occur. Absent an understanding of context, it is difficult, if not impossible, to comprehend and fully appreciate the factors influencing entrepreneurial decision-making processes. Therefore, this study begins with an overview of the context in which rural Chinese entrepreneurs viewed decisions concerning choice of organizational form. While admittedly doing little justice to the enormity of each issue discussed in the following paragraphs, this section briefly outlines some major milestones that brought about the conditions under which entrepreneurial choice has been made in rural China since the death of Chinese Communist Party (CCP) leader, Mao Zedong, in 1978.

\section{The 100 Flowers Campaign}

The CCP came to power in 1949 under the direction of Mao Zedong. The early 1950s were a time of relative political stability despite growing social dissatisfaction as the CCP reveled in its victory over the Nationalist Party. But as the decade wore on, instability gradually crept in. An early defining event was the Hundred Flowers Campaign in 1957 when Mao encouraged intellectuals to openly criticize the CCP that had wrested control of the government from the Nationalists eight years earlier. But when the intellectuals spoke up, some were forced to recant, some were imprisoned in labor camps for "reeducation," and still others suffered a worse fate. The "Rightists" who followed Chairman Mao's direction to criticize the CCP found that the opportunity to speak up was better done with praise than criticism, leading to a reluctance to criticize Mao and his party.

\section{The Great Leap Forward}

Soon after, the Great Leap Forward in 1958 promised that the newly founded Peoples' Republic of China would catch up and then surpass England and the United States in industrial production. "Backyard steel furnaces" were set up and rural residents were strongly encouraged to donate and melt down steel-containing metal household goods. The idea was to accelerate national steel production, giving China a "great leap forward" toward economic development. But instead of the intended economic push forward, township and village leaders, in an effort to show their patriotism, exaggerated the amount of steel production in the backyard steel furnaces. The result was gross overestimation of national steel output. When the CCP realized two years later what had occurred, they were left with little more than thousands of steel melting furnaces but little steel in what Kuhn (2000) has termed the huge fall backward.

The irony lies not in the fact that the practice was virtually doomed from the beginning. Instead, unintended consequences proved beneficial as small factories developed alongside the backyard steel furnaces. This contributed to development of a cellular economy (Prybyla, 2000; Starr, 2001a) in which some factories were owned by the state, others by county governments, and some by communes that were the precursors of the township and village enterprises that would evolve in the 1980s. 


\section{The Great Cultural Revolution}

In just a few years following the Great Leap Forward, a defining decade came about in the social experiment that thrust China into the Great Cultural Revolution in 1966. Designed to implement socialism's ideals of equality, the Cultural Revolution caused many to suffer under the watchful eye of the Red Guard. Although ideologically there was separation of the CCP from the government, in reality little separation was actually present. A self-reinforcing mechanism provided tight control through two means. First, each level of the Party held the power to appoint members to the hierarchical layer just below it. Second, the Party itself (rather than an independent third party) monitored those whom it appointed. This ensured that party policies were implemented by the Red Guard.

The privileged class that had arisen and enjoyed economic prominence in the 1950s found the tables turned when they became targets of the CCP during the Cultural Revolution. But those who were largely responsible for the Cultural Revolution in the name of socialist equality became the new perpetrators of injustice. During this dark time in China's history, implementation of Party policies reached deep into China. Individual families were required to house and support members of the Red Guard, and few dared speak against the Party with members of the military living under the same roof. The goal of equality resulted in mass oppression of those it intended to liberate.

\section{Reform Era}

Soon after China emerged from the Cultural Revolution, Deng Xiaoping rose to power in 1978 two years after Mao's death. Deng was highly instrumental in leading China and the CCP away from the economic and social turmoil of the Cultural Revolution and toward economic reform. An arch enemy of Mao, Deng himself had been a target of the CCP during the Cultural Revolution. He had been branded a counterrevolutionary and publicly humiliated. But it was his tenacious idea of "socialism with Chinese characteristics" that eventually brought about Mao's vision of a prosperous China (Prybyla, 2000). Deng, with less ideological fervor than Mao but with more of a practical view of socialism, believed that economic reform was justified as long as it prompted growth without diluting CCP control (Starr, 2001a). In 1978, Deng was instrumental in espousing the four modernizations that were begun in 1979: agriculture, industry, defense, and science and technology (Third Plenum of the Eleventh Party Congress, 1978).

\section{Student Pro-Democracy Movement}

Economic reform quickly took root under Deng's leadership, but the student pro-democracy movement at Tiananmen Square in the nation's capital of Beijing was a stark reminder that the CCP had not lost control of the populace. While peaceful demonstrations were allowed in China, this incident on June 4, 1989 occurred after a sixweek standoff between student demonstrators and government officials. After repeatedly ordering the students to disband, the CCP directed the People's Liberation Army to use force to disperse the crowd. This was interpreted by some business owners as a warning that the Party continued as a dominant factor in China's affairs and that the CCP would not hesitate to reassert its influence when necessary, sending many private business owners scrambling to align themselves with Party ideology. The year following the confrontation, for example, there was a sixteen-fold increase in the number of privately-owned businesses registering as township and village enterprises, a collective form of ownership, in Sichuan Province (Guo, Lu, \& Song, 1993).

\section{Since the 1990s}

The 1990s and the early part of the new millennium have witnessed ongoing economic growth and political changes. This most recent period, although fraught with its own difficulties, has done well to avoid many mistakes of the past while building on successes. The rise of the fourth generation of political leaders began toward the latter part of the 1990s as many of the third generation leaders, such as Jiang Zemin, Zhu Rongji, and Li Peng, entered their 70s. In contrast to third generation leaders, many fourth generation leaders have expertise in economics, finance, and law (Cheng, 2000a). In addition, there is less focus on a single charismatic leader such as occurred during the Mao and Deng eras, shifting instead to a shared decision-making body (Scalapino, 1999). 
A shift in attitude toward criticism has also come about in the last decade. China's government has been more accepting of critical political discourse (Cheng, 2000b). Indeed, China has allowed the publication of books criticizing government policy, a stance that would have been unheard of 30 years ago. For example, He Qinglian wrote a volume criticizing the economic and social policies of the country's leaders, even publishing her book in Beijing, the nation's capital city (He, 1998a). However, the CCP remains on guard against any movements that might threaten social stability. The rise of the quasi-religious sect Falun Gong in 1992 concerned Party leaders. Falun Gong made inroads through members and supporters in the military, government, and large numbers of the populace. In contrast to the CCPs tolerance of books such as He's (1998a), it was the perceived ability of the Falun Gong to mobilize the masses that threatened the CCP (Starr, 2001b).

China became a member of the World Trade Organization (WTO) in 2001 and, despite strained foreign relations with the United States, an influential member of the WTO. For its part, the U.S. created difficult conditions under which to forge new relationships. On May 8, 1999, three U.S. bombs struck the Chinese embassy in Belgrade, provoking a storm of protest in China against the U.S. This incident came on the heels of the U.S. announcement to use Taiwan as part of the Theater Missile Defense system (Cheng, 2000b).

Income disparity rose to unprecedented levels during the 1990s while China's unemployment statistics reached their highest levels since 1949. One-third of private savings were in the hands of $0.01 \%$ of the population (He, 1998b). The increase in unemployment was compounded by the faltering state-owned enterprise (SOE) sector, forcing layoffs of employees who believed they had lifetime job security (Hu, 2000; Shambaugh, 1998). This action itself of laying off employees ran counter to the longstanding notion of the "iron rice bowl," wherein employees in SOEs could, it was thought, count on permanent employment, health care, and retirement income.

It has been over a half-century since the CCP came to power. China has since had five constitutions, including three revisions as recently as 1988, 1993, and 1999 (Ho, 2001), and has seen dramatic, sweeping political, social, and economic changes. These events have surely not gone unnoticed by those contemplating organizational ownership. Those who made entrepreneurial choices during the previously described period are the focus of this study. It is important to understand the institutional setting in which these choices were made - the political, social, and economic ramifications of the past bring with them the context for entrepreneurial choice in the present.

\section{ENTREPRENEURIAL CHOICE IN AN AMBIGUOUS ENVIRONMENT}

\section{Ambiguity of Property Ownership}

It is with hesitation that one should even use the word "ownership" when discussing China during its emergence since Mao's death. Ownership did not connote to Chinese the ordinary meaning it does for those accustomed to clearly defined property rights (Selden and Lu, 1993). Despite over fifty years of legal maneuvering, the question of property ownership is fraught with ambiguity. Certain areas of the country such as the urban and coastal regions have taken liberties with this ambiguity. For instance, as economic growth created a surge in real estate development, more successful regions such as the southern coastal cities rapidly developed real estate through lease transfer rights $(\mathrm{Ho}, 2001)$. However, much of rural China remains at a loss as to how to legally assign property ownership.

A complicated facet of property right ambiguity concerns ownership by collectives such as township and village enterprises (TVEs). The leftover heritage of the Great Leap Forward, TVEs were officially recognized in the 1980s when agricultural communes were being gradually dismantled. The Great Leap Forward provided the context for growth of rural collectively-owned property from 1959 to 1962. During this brief period, ownership rights among three stakeholders - communes, production brigades, and productions teams - was at issue. In 1962, the CCP developed what is commonly called the 60 Articles (officially termed the Work Regulations for the Rural People's Communes) that designated the production team as legal owner of the land on which production occurred (Ho, 2001). This provided the legal basis of group ownership until the 1980s when communes were done away with during decollectivization and replaced by TVEs. But even now, ownership of land by TVEs remains an ambiguous issue (Ho, 2000; 2001). 


\section{The Economy in Transition}

While it is clear that contemporary China has moved to a market economy and is no longer a transitional economy (Meyer, 2008), there are pockets of contrast with traditional economic thinking regarding precisely what constitutes a market economy. For example, from the perspective of property ownership, China does not meet qualifications necessary for a true market economy in terms of unambiguous property rights (Oi and Walder, 1999; Putterman, 1995). One characteristic of a market economy is high levels of privatized property ownership. But as a factor of production, land remains under state control in China. Although use rights can now be legally leased and transferred to a great extent for real estate and agricultural purposes, outright ownership ultimately resides with the state. As mentioned, the more economically developed regions make use of sublease and other use transfer provisions for economic gain, but this is rare in rural regions. "The pricing of rural land is still an ideological taboo which inhibits an economically efficient exchange of land use rights (Ho, 2001: 417)." The fact that local governments were historically heavily involved in the operation of businesses in rural China has impeded rural economic reform. Rather than focus on efficiency, local governments often had other interests that guided their actions toward local industry (Wong, 1987; Nee, 1992).

There is no doubt that China has transitioned from its former command economy toward a market-based economy (Byrd, 1991; Naughton, 1987), but the reasons underlying this transition are debatable. For example, Williamson (1991) suggests that minimization of transaction costs is a key variable affecting organizational form. The most cost effective form-market, hybrid, or hierarchy — becomes the predominant mode even taking into account property rights, contract law, reputation, and environmental uncertainty. Others argue that the situation is more complex than simply cost minimization. Boisot and Child (1988) suggest that a transaction cost perspective such as that proposed by Williamson (1991) is too simplistic to understand the complex interrelationships in transitional economies.

Regardless of the underlying reasons for the economic transition, it is clear that China's economy has not functioned as a pure market economy throughout its reform era. While Nee (1992) and Kuhn (2000b) recognize that market reform favoring private enterprise has constituted the overwhelming majority of transition in China, Nee (1992) suggests that hybrid forms of organization developed in reaction to the transition to a market economy given ambiguity of property rights. Boisot and Child (1996) suggest that rather than transitioning toward a market economy, China developed a form of economy they termed network capitalism. This varies from the capitalism of developed nations in that low information codification (e.g., ill-defined property rights, vague legal mechanisms) and reliance on strong, reciprocal social connections (guanxi) results in an economy that contains features of both capitalism via reliance on free market mechanisms as well as socialism via centralized redistributive activity and factor resource access via governmental bodies.

\section{Sociopolitical Legitimacy of TVEs and Private Business}

Certain forms of organizational structuring in historically Marxist-Leninist economies may be viewed as attempts to gain social and political legitimacy. For example, Tsang (1996) suggested a contradiction between entrepreneurial activity and Marxist ideology, positing that individual business owners may work closely with the state to gain legitimacy. Hu (2000) makes a similar observation concerning Chinese business forms beginning in the reform era extending from Deng's appointment in 1978 and the post-reform economy since Deng's death in 1997.

Starr (2001c) discusses these issues from the perspective of the ideological changes that have swept China since 1949. Starr draws inferences from Marxist ideology as presented by both Mao and Deng in light of the failed attempts at radical socialism during China's Great Leap Forward and the Cultural Revolution. He suggests that the $\mathrm{CCP}$ in post-Maoist China has steadily lost power, resulting in dependence by the state on individual businesses for economic growth at the same time that individual businesses depend on the state for capital resources.

\section{Resource Dependence and the Contradiction of Rural Private Enterprise}

Pfeffer and Salancik's (1978) resource dependence provides a rationale in which Williamson's (1991) transaction cost economic arguments may be refuted. That is, collectively-owned businesses are well-accepted 
economically and politically in China, but private enterprise historically lacked the social legitimacy (at least in some rural areas) as well as some of the economic and political benefits of collective ownership. Nevertheless, some individuals continue to enter into private entrepreneurial ventures, giving up the benefits afforded collectivelyowned competitors.

\section{Institutional Ambiguity}

Institutional processes encountered by entrepreneurs, long recognized as influencing economic activity (Wolf, 1955), have created a unique environment for entrepreneurs. Where dominant ideologies have been fractured, legitimization is retrospective rather than prospective, and actions become rules rather than rules governing actions. In other words, it becomes an environment of meso-institutions (Droege and Brown-Johnson, 2007). Perhaps this is deliberate on the part of the state to allow experimentation and prevent social upheaval (Ho, 2001) given that institutional ambiguity can serve a protective function. If China were to sort out issues regarding property rights the result could be explosive as individuals involved in collective ownership as well as those with private ownership perceive changes, both positive and negative, regarding their property rights (Keith, 1994).

A society's ideology may at times contribute to institutional ambiguity. As ideological values shift, the institutional environment can hold conflicting views of the social context in which organizations operate (Naughton, 2008). An example from socialist-Zionist ideology is illustrative of this. Simons and Ingram (1997) examined kibbutzim (Israeli cooperatives) which were prohibited from hiring labor. Using data from 1951 to 1965, a period in which rapid ideological changes occurred, their study found that ideological principles were violated in response to resource dependence pressure as well as from economic incentives, concluding that organizations may violate and forfeit ideological principles when countervailing forces override the strength of such forces. The indecision arising from ideological changes may contribute to institutional ambiguity as societal values shift, creating conflicting pressures that are, under more stable conditions, used to guide behavior and choice. China's institutional development has followed a similarly ambiguous path.

\section{ENTREPRENEURIAL CHOICE: COLLECTIVE VERSUS PRIVATE ENTERPRISE}

It would be naive to suggest that the entire weight of the evidence falls on the side of collective types of organization as the most rational entrepreneurial choice for Chinese entrepreneurs during the nation's transition. Indeed, collectively-owned organizations had their own particular problems. For instance, Guo (2001) writes of a case in Yunnan Province in which villagers revolted against expropriation of property by county government. The revolt came when county officials announced on local television that peasants should clear the fields by a given date, after which bulldozers would clear the land for a new proposed government sponsored enterprise. Those who defied, the broadcast warned, would bear the consequences. Despite the warnings, the villagers mounted opposition to the expropriation. In the end, however, the local government succeeded.

This illustrates another paradox of Chinese contemporary history-the trend has been to decentralize decision-making power to lower levels of government in an effort to move toward market reform (Jin, Qian \& Weingast, 2005). But in cases such as this, individual autonomy without government interference remains largely illusive (Li and O'Brien, 1996; Lu, 1997). This incident suggests that rather than inhibiting government interference, the interference now simply comes from a lower governmental unit rather than from central government (Zweig, 1992).

A more positive example in Xinji, located in Hebei Province, shows the benefits of private rural entrepreneurial activity in conjunction with cooperative government. Local officials in Xinji cooperated with private enterprise to form the Xinji Fur and Leather Trade Center (FLTC). Through cooperative effort between local government and private entrepreneurs, the FLTC greatly expanded the opportunities of private business. Over time, Xinji became China's leading supplier of fur and leather with economic benefits accruing to both government and private entrepreneurs (Blecher and Sheu, 2001).

Current statistics comparing the number of domestic enterprises with the number of privately owned enterprises in China from 1999 until 2007 indicate the Xinji success is not isolated. While the grown of domestic 
firms mirrored national overall growth during this time, (the number of firms doubled and the output value of these firms increased fivefold), the private enterprise growth was 12 times the number of firms in 1999. The rate of output increased 28 times the 1999 output. It appears that private enterprises are increasingly being recognized as viable business options.

The historical choices between collective and private enterprise are thus not discrete events consisting of economically rational options. Instead, these choices are an interrelated mix of resource access, sociopolitical legitimacy, power struggles, and national institutional context. Indeed, efforts to isolate discrete mechanisms may result in removing entrepreneurial strategic choice from its context (Zahra, 2007) and thus miss the more complex but highly entangled phenomena that make up strategic choice.

\section{CONCLUSION}

The dilemma facing entrepreneurs considering the events described previously was whether the unclear benefits of individual ownership outweighed the risks. It is worth noting that some private enterprises disguised themselves as collectively owned "red hat" companies. An interesting debate is whether this was a strategy to gain benefits of collective ownership, reduce the risk of private enterprise, or a combination of both strategies. For example, access to capital from state-owned banks was typically more available to TVEs than to private entrepreneurs. In addition, private enterprises were subject to arbitrary taxation imposed by local government, a risk not encountered by TVEs.

Such illustrations support our contention that path dependence historically created a limited array of entrepreneurial choices in rural China including various forms of collective and private business ownership. However, collective ownership historically gave rural Chinese entrepreneurs increased sociopolitical legitimacy thereby increasing access to resources such as capital; however, many rural entrepreneurs during China's reform era chose private rather than collective ownership, an economically illogical choice. This seemingly illogical choice resulted in changes in China's institutional fabric such that the most historically illogical choice-private business ownership - became the most logical choice. This suggests that entrepreneurial choice extends beyond economic rationality to a more complex environment of options.

\section{AUTHOR INFORMATION}

Dr. Scott Droege is Associate Professor of Management at Western Kentucky University. His research interest is in the effect of institutional change on entrepreneurial strategy in emerging markets. He has taught and conducted extensive research in the Asia.

Dr. Michelle Lane is an Assistant Professor of Management at Western Kentucky University. Her research interests are in the areas of women's entrepreneurship, technology's influence on firm performance, and social entrepreneurship.

Dr. Shane Spiller is an Assistant Professor of Management at Western Kentucky University. His research interests include motivation at the micro and macro level, and ethical decision making.

\section{REFERENCES}

1. Blecher, M. \& V. Shue (2001). Into leather: State-led development and the private sector in Xinji. The China Quarterly, 166, 368-393.

2. Boisot, M. \& J. Child (1988). The iron law of fiefs: Bureaucratic failure and the problem of governance in the Chinese economic reforms. Administrative Science Quarterly, 33(4), 507-528.

$3 . \quad-----(1996)$. From fiefs to clans and network capitalism: Explaining China's emerging economic order. Administrative Science Quarterly, 37, 1-27.

4. $\quad$ Byrd, W. A. (1991). The Market Mechanism and Economic Reforms in China. Armonk, NY: M.E. Sharpe.

5. Cheng, L. (2000a). Jiang Zemin's successors: The rise of rise of the fourth generation of leaders in the PRC. China Quarterly, 161, 1-40. 
6. Cheng, L. (2000b). China in 1999. Asian Survey, 40(1), 112-132.

7. Guo, X. (2001). Land expropriation and rural conflict in China. The China Quarterly, 166, $422-439$.

8. Guo, Z., J. Lu \& S. Ning (1993). China’s changing ownership structure. Social Sciences in China, 1, 178192.

9. He, Q. (1998a). Xiandaihua de xianjing: Dangdai Zhongguo de jingji shihui wenti (The pitfall of modernization: Economic and social problems of contemporary China). Beijing: Jinri Zhongguo chubanshe.

10. -------(1998b). Wealth and poverty-An analysis of China's current polarization. China and the World, 22.

11. H, P. (2000). The clash over state and collective property: The making of the Rangeland Law. The China Quarterly, 161, 240-263.

12. -------(2001). Who owns China's land? Policies, property rights and deliberate institutional ambiguity. The China Quarterly, 166, 394-421.

13. $\mathrm{Hu}, \mathrm{X}$. (2000). The state, enterprises, and society in post-Deng China: Impact of the new round of SOE reform. Asian Survey, 40(4), 641-657.

14. Jakobson, L. (1998). Tiananmen's spark of hope. In A Million Truths: A Decade in China. New York: M. Evans and Company.

15. Jin, H., Y. Qian \& B.R. Weingast (2005). Regional decentralization and fiscal incentives: Federalism, Chinese style. Journal of Public Economics, 89, 1719-1742.

16. Keith, R. C. (1994). China's Struggle for the Rule of Law. New York: St. Martin's Press.

17. Krug, B. \& H. Hendrischke (2008). Framing China: Transformation and institutional change through coevolution. Management \& Organization Review, 4, 81-108.

18. Kuhn, R. L. (2000). Reform and Restructure. In Made in China: Voices from the Revolution. New York: TV Books.

19. Li, L. \& K. J. O’Brien (1996). Village and popular resistance in contemporary China. Modern China, 22(1), 28-61.

20. Lu, X. (1997). The politics of peasant burden in reform China. The Journal of Peasant Studies, 25(1), $113-$ 138 .

21. Meyer, M. (2008). China's second economic transition: Building national markets. Management \& Organization Review, 4, 3-15.

22. Mintzberg, H. \& F. Westley (1992). Cycles of organizational change. Strategic Management Journal, 13, 39-59.

23. Naughton, B. (1987). The decline of central control over investment in post-Mao China. In David M. Lampton (ed.), Policy Implementation in Post-Mao China (pp. 51-80). Berkeley, CA: University of California Press.

24. ---- (2008). The Chinese economy. Transitions and growth. Asian Business and Management, 7, 511 -513.

25. Nee, V. (1992). Organizational dynamics of market transition: Hybrid forms, property rights, and mixed economy in China. Administrative Science Quarterly, 37, 1-27.

26. Oi, J. C. \& A. G. Walder (1999). Property rights in the Chinese economy: Contours of the process of change. In J. C. Oi \& A. G. Walder (eds.), Property Rights and Economic Reform in China. Stanford, CA: Stanford University Press.

27. Peng, M.W. (2003). Institutional transitions and strategic choices. Academy of Management Review, 28, 275-296.

28. Peng, M.W., D.Y.L. Wang \& Y. Jiang (2008). An institution-based view of international business strategy: A focus on emerging economies. Journal of International Business Studies, 39, 920-936.

29. Prybyla, J. (2000). The Chinese communist economic state in comparative perspective.In D. Shambaugh (ed.), The Modern Chinese State (pp. 188-215), United Kingdom: Cambridge University Press.

30. Putterman, L. (1995). The role of ownership and property rights in China's economic transition. The China Quarterly, 144, 1047-1065.

31. Scalapino, R. A. (1999). The People's Republic of China at 50. National Bureau of Asian Research Analysis, 10(4), 7.

32. Selden, M. \& A. Lu (1993). The reform of land ownership and the political economy of contemporary China. In M. Selden (Ed.), The Political Economy of Chinese Development. Armonk, NY: M.E. Sharpe. 
33. Shambaugh, D. (1998). The CCP's Fifteenth Congress: Technocrats in command. Issues and Studies, 34(1), $1-37$.

34. Simons, T. \& P. Ingram (1997). Organization and ideology: Kibbutzim and hired labor, 1951-1965. Administrative Science Quarterly, 42(4), 784-814.

35. Starr, J. B. (2001a). Sources of rural discontent. In Understanding China: A Guide to China's Economy, History, and Political Culture (pp. 108-126). New York: Hill and Wang.

36. - - - (2001b). China's cities: Unemployment, corruption, and anomie. In Understanding China: A Guide to China's Economy, History, and Political Culture (pp. 127-145). New York: Hill and Wang.

37. ----(2001c). China's economy: Who owns what, who works where, and who makes the decisions. In

38. Understanding China: A Guide to China's Economy, History, and Political Culture (pp. 72-89). New York: Hill and Wang.

39. Third Plenum of the Eleventh Party Congress (1978), December.

40. Tsang, E.W.K. (1996). In search of legitimacy: The private entrepreneur in China. Entrepreneurship: Theory and Practice, 21(1), 21-31.

41. Wang, H. (1998). Dangqian nongcun tudi chengbao jingying gaunli de xianzhuang ji wenti (The present situation and problems facing the management and administration of rural lease land). Zhongguo nongcun guancha, (5), 56-77.

42. Williamson, O. (1991). Comparative economic organization: The analysis of discrete structural alternatives. Administrative Science Quarterly, 36(2), 269-297.

43. Wolf Jr., C. (1955). Institutions and economic development. American Economic Review, 45, 867-883.

44. Wong, C.P.W. (1987). Between plan and market: The role of the local sector in post-Mao China. Journal of Comparative Economics, 11, 385-398.

45. Zahra, S.A. (2007). Contextualizing theory building in entrepreneurship research. Journal of Business Venturing, 22(3), 443-452.

46. Zweig, D. (1992). Urbanizing rural China: Bureaucratic authority and local autonomy. K. G. Liberthal and D. M. Lampton (eds.), Bureaucracy, Politics and Decision Making in Post-Mao China. Berkeley, CA: University of California Press. 
NOTES 